\title{
Modeling of Source Rocks in Moliqing Basin of Yitong Graben, Northeast China
}

\author{
Obed Kweku Agbadze*, Jiaren Ye, Qiang Cao, Gerardo Emilio Di Trolio Bravo \\ Key Laboratory of Tectonics and Petroleum Resources, China University of Geosciences, MOE, Wuhan, China \\ Email: *oagbadze@outlook.com
}

How to cite this paper: Agbadze, O.K., Ye, J.R., Cao, Q. and Bravo, G.E.D.T. (2019) Modeling of Source Rocks in Moliqing Basin of Yitong Graben, Northeast China. International Journal of Geosciences, 10, 439-453.

https://doi.org/10.4236/ijg.2019.104025

Received: March 20, 2019

Accepted: April 27, 2019

Published: April 30, 2019

Copyright $\odot 2019$ by author(s) and Scientific Research Publishing Inc. This work is licensed under the Creative Commons Attribution International License (CC BY 4.0).

http://creativecommons.org/licenses/by/4.0/

\begin{abstract}
Moliqing basin is a continental sedimentary basin in the northeast of China, between Changchun and Jilin. The source rocks characterization was done using the data of three wells to define the generative potential, kerogen type and thermal maturity. Basin Mod software was used for the models. The three Eocene source rock formations in the basin are Shuangyang, Sheling and Yongji. Shuangyang is the most important due to its quantity and maturity levels of kerogen with very good generative potential (TOC between $2 \%-4 \%$ ) towards the southern region of the basin. According to the Tmax values, all three source rocks reached the mature stage, and the levels increased from early mature for the Yongji formation, to late mature for some locations of the Shuangyang formation. The $1 \mathrm{D}$ and $2 \mathrm{D}$ modeling reconstructed shows that the heat flow developed in the basin laid between 64 and $78.1 \mathrm{~mW} / \mathrm{m}^{2}$ and had maximum heat flow location towards the center of the basin.
\end{abstract}

\section{Keywords}

BHT, Pyrolysis Tmax, Hydrocarbons, Eocene Source Rock, Moliqing Basin, Yitong Graben

\section{Introduction}

Moliqing basin is located at the north east of China, between Changchun and Jilin. It is part of three geologic subdivisions that form the Yitong Graben basin, the other two being Chaluhe and Luxiang basins [1].

The basin has been subjected to active exploration by the Chinese Jilin Oil Company since 1985 and more than 50 wells have been drilled with discovered certifying reserves of $3317 \times 10^{4}$ tons oil and $13.29 \times 10^{8} \mathrm{~m}^{3}$ gas.

The studies [2] and [3] identified four cenozoic tectonic evolution divisions and the further three uplift events which resulted in major regional unconformi- 
ties in the basin. Additionally, the boundary faults experience a process of right lateral extrusion and uplift [4].

Thermal history and petroleum generation of the basin was conducted [5] and the source rocks have also been studied and discussed, with the Shuangyang formation as the principal source of the basin [6] among others.

Nevertheless, measured vitrinite reflectance considered the major thermal indicator was not used for the calibration because of the questionable measured values. Instead, the basin temperature and the pyrolysis Tmax were used as thermal maturity indicators.

However, in this study, the Tmax based calculated Vitrinite reflectance was used in addition to the BHT (Bottom Hole Temperature) and the pyrolysis Tmax so as to provide an additional verification method to best describe the basin thermal conditions.

\section{Geological Setting}

The Yitong graben is a petroliferous late-Mesozoic and Cenozoic slip-extensional basin. This basin is part of the Tanlu fault zone considered done of the largest continental strike-slip faults in the world [7] and extends from north east to south west of the northern Chinese province of Jiling covering approximately $2200 \mathrm{~km}^{2}$ with a length of $140 \mathrm{~km}$ trending NW and a width that ranges between 12 and $20 \mathrm{~km}$ trending EW [5]. Furthermore, it borders at the north and south with the Dahei and Nadanhada Mountains respectively.

Based on its geological characteristics and basin style, is divided into three subunits; from NE to SW, the Chaluhe fault depression, the Luxiang fault depression and the Moliqing fault depression [1] [8].

The Moliqing basin has been divided in four areas according to its geological features: the Kaoshan sag, the Ma'anshan fault-step belt, the Jianshan uplift, and the Xiaogushan slope belt [5] (Cao, Ye, et al. 2011) (Figure 1).

The Moliqing basin contains seven different sedimentary rocks formations from the Eocene to the Quaternary, overlying a pre-tertiary basement Figure 2. The distribution of the sediment thicknesses inside the Moliqing depression is deeper at the northern area of the basin, diminishing in depth towards the southern zone. The total thickness of the sediment ranges from $2000 \mathrm{~m}$ to 5000 m.

\section{Data and Methods}

The input data required to run the BasinMod 1-D of our study are derived from three wells in the Moliqing basin: well Y8, Y34, and Y46 (Figure 3).

The eroded thickness [3] (Table 1), present thicknesses of each stratigraphic unit, top and base wellbore depths, and the lithology mixes data are derived from composite well logs. Biostratigraphy is derived from the ditch cuttings which were washed, separated and then analyzed for micro fauna (Foraminifera) and flora (spores and pollens). The location of wells (Figure 3), kerogen types, 


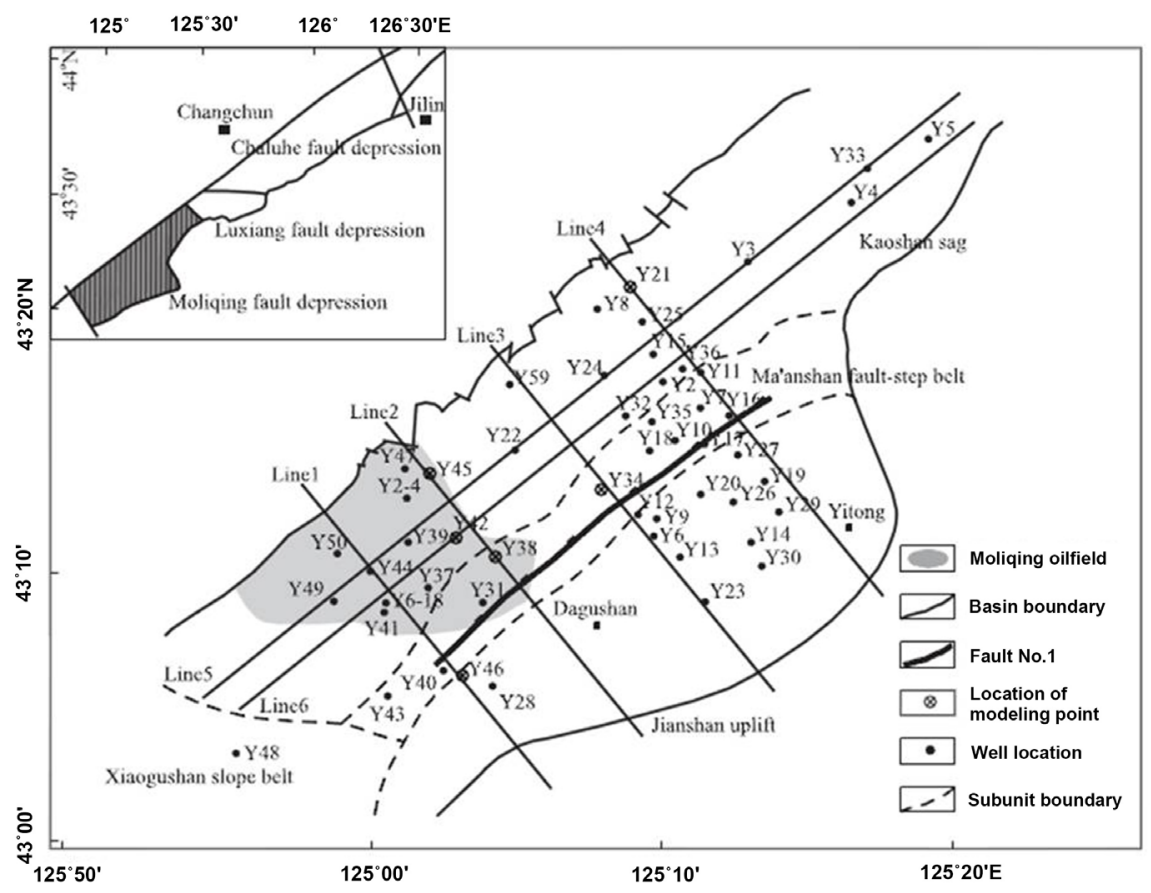

Figure 1. Tectonic units of the Moliqing fault depression.

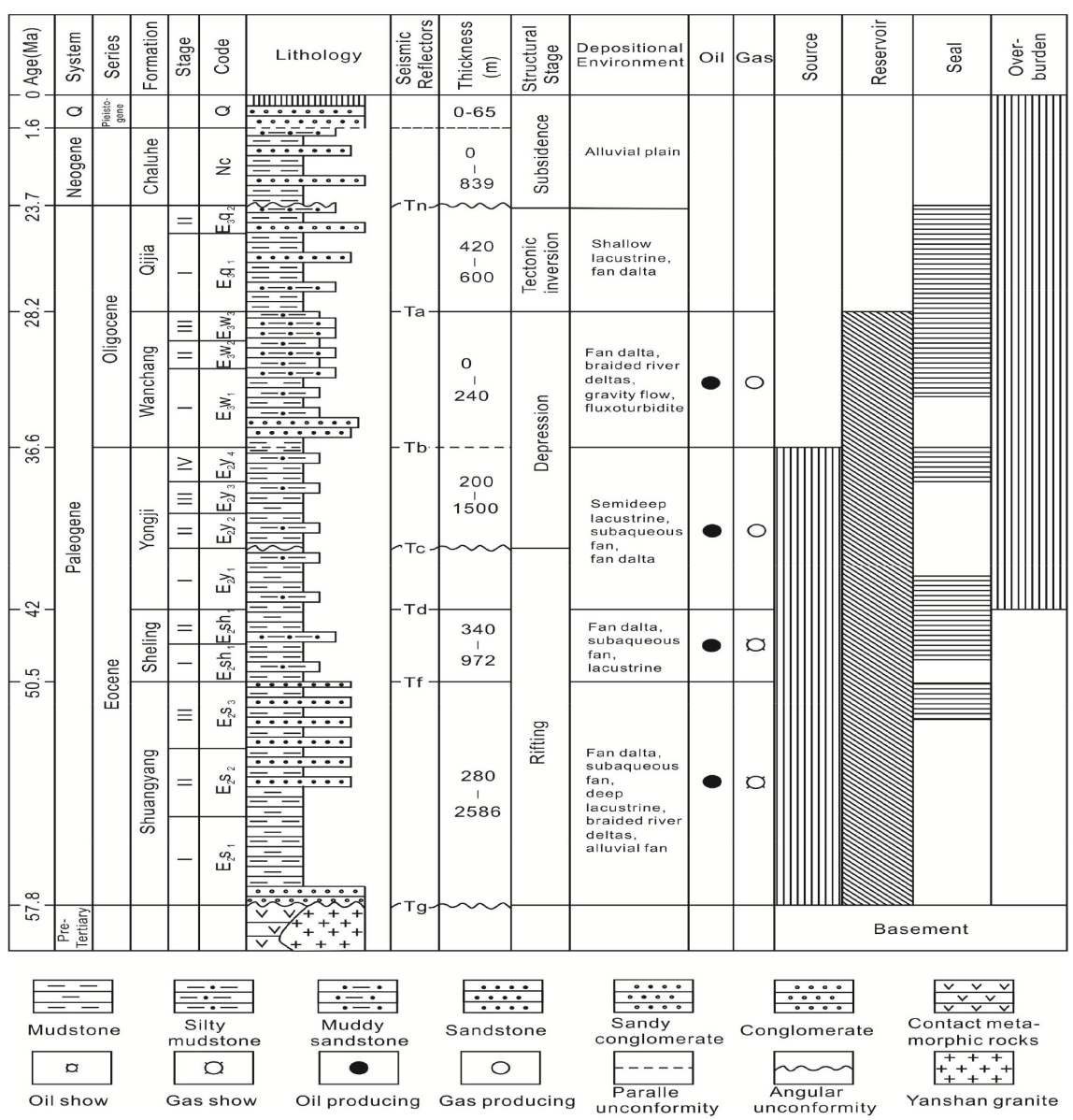

Figure 2. Stratigraphic columns in the Moliqing basin. 


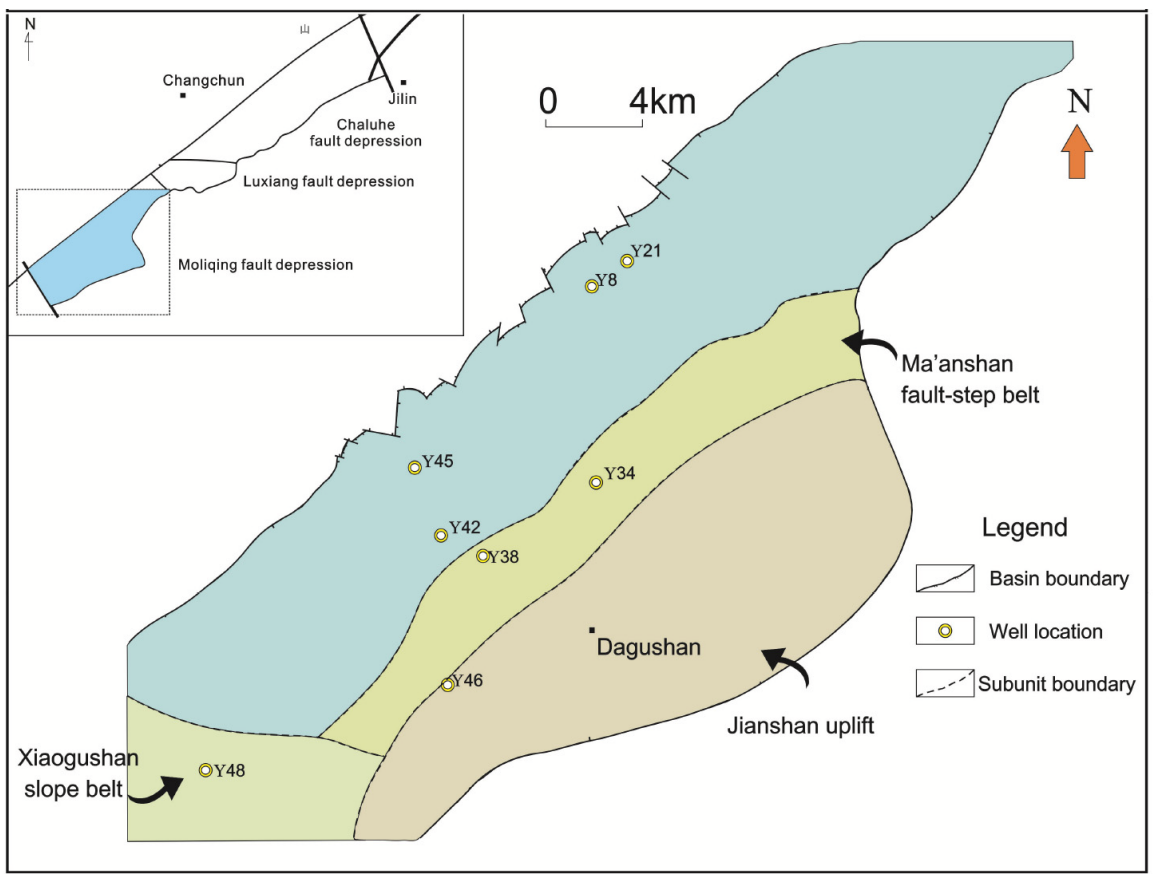

Figure 3. Location of the modeled Moliqing basin wells.

Table 1. Calculated eroded thicknesses for the wells used in the 1D modeling (Modified after [3]).

\begin{tabular}{cccc}
\hline \multirow{3}{*}{ Well } & \multicolumn{3}{c}{ Missing thickness [m] } \\
\cline { 2 - 4 } & $\mathbf{4 2} \mathrm{Ma}$ & $\mathbf{3 0 ~ M a}$ & $\mathbf{1 0 ~ M a}$ \\
\hline Y8 & 300 & 800 & 500 \\
Y34 & 200 & 600 & 200 \\
Y42 & 240 & 635 & 200 \\
Y46 & 200 & 700 & 200 \\
\hline
\end{tabular}

total organic carbon (TOC), kinetic algorithms and results of pyrolysis analyses, and organic thermal indicators include vitrinite reflectance values; the water-sediment interface temperatures after [9] and subsurface bottom hole temperatures (BHTs) through time, the short term sea level proposed by [10] geologic time scale [11], the density of asthenosphere $(\rho \mathrm{m})$ and water $(\rho \mathrm{w})$ are 3.40 $\mathrm{g} / \mathrm{cm}^{3}$ and $1.03 \mathrm{~g} / \mathrm{cm}^{3}$ respectively, the Beta factor $(\mathcal{B})$ and thickness of lithosphere (a) can be obtained accepting default values of 2 and $125 \mathrm{~km}$, respectively, all mixed parameters, the initial porosity, reciprocal and exponential compaction factors, the matrix density, matrix thermal conductivity, and matrix heat capacity are adopted from the default values in BasinMod Software package.

The data and materials for BasinMod 2-D are 1-D well data and Seismic Lines

\section{2, 5, (Figure 4) maps coordinates.}

In summary, the modeling processes, its methodology and references are in Table 2 below. 


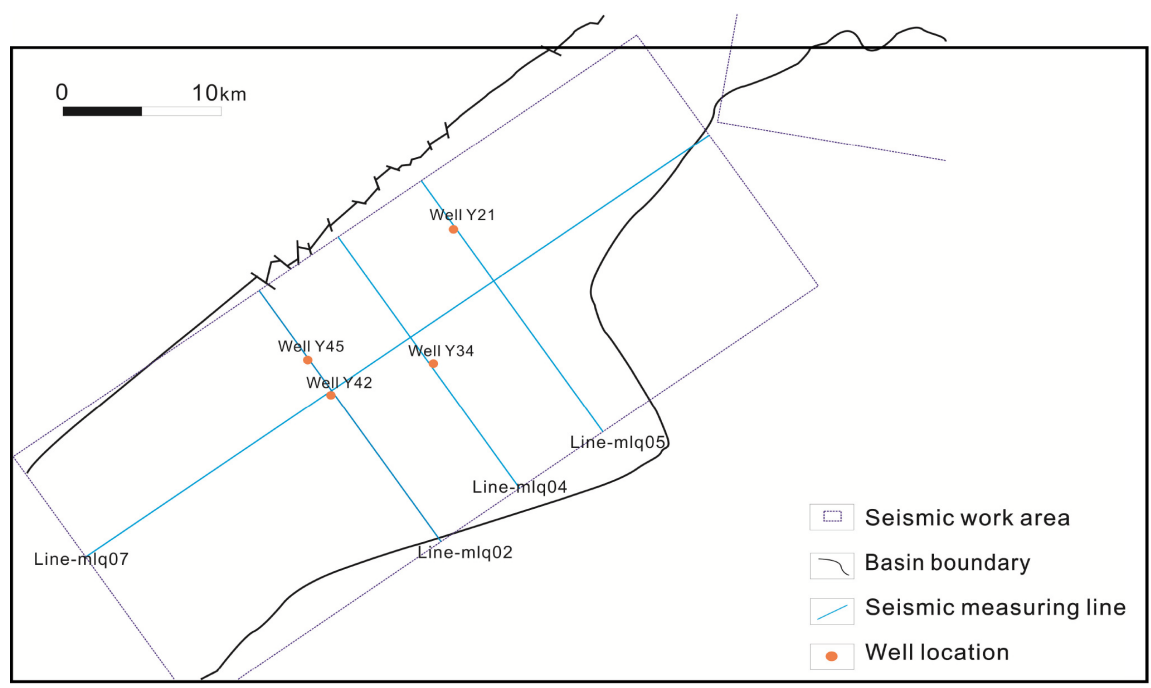

Figure 4. Locations of the cross sections and wells modeled.

Table 2. Mathematical methods selected to build basin models.

\begin{tabular}{ccc}
\hline Modeled process & Mathematical method & Reference \\
\hline Burial history & Backstripping (decompaction) & {$[12]$} \\
Geothermal Calculation (Heat Flow) & Transient equation & {$[13]$} \\
Maturity Calculation (Vitrinite Reflectance \%Ro) & LLNL Easy \%Ro & {$[14]$} \\
Permeability calculation & Modified Kozeny-Carman & {$[15]$} \\
Compaction method & Fluid flow & {$[13]$} \\
Porosity reduction method & Bmod 1-D fluid flow & Statoil \\
Generation & Organofacies & {$[16]$} \\
\hline
\end{tabular}

\section{Results Interpretation and Discussion}

\subsection{One Dimensional Modeling}

The calculations related to this modeling approach include geohistory/burial history, heat flow, temperature, thermal maturity, timing of petroleum generation and pressure.

The 1D model calibration of the Moliqing basin was based on the comparison between the registered formation temperatures obtained during the Bottom Hole Temperature (BHT) tests against the modeled temperature curves.

\section{Wells Results}

\section{Well Y8}

The northwest border of the Moliqing basin in the Kaoshan sag is the location for Well Y8.

\section{Erosion and sedimentation rate}

The basin experienced three uplift processes, producing erosions and cooling effects on the formations and these took place during $42 \mathrm{Ma}, 30 \mathrm{Ma}$ and $10 \mathrm{Ma}$ registering erosions of $300 \mathrm{~m}, 800 \mathrm{~m}$ and $500 \mathrm{~m}$, respectively. The missing 
eroded thickness at this Well is the highest among the studied locations.

The burial history (Figure 5) shows an increase sedimentation rate tendency from the beginning of the basin formation (57.8 Ma) until the starting point of the second erosion event (30 Ma), with values beginning from $63 \mathrm{~m} / \mathrm{Ma}$ for the Shuangyang formation, up to $147 \mathrm{~m} / \mathrm{Ma}$ for the Yongji formation. This increase was closely followed by an increment in temperature, causing the Shuangyang formation sediments to reach temperatures over $100^{\circ} \mathrm{C}$. After the second erosion event, the sedimentation rate changed its tendency and started decreasing the magnitude, being $38 \mathrm{~m} / \mathrm{Ma}$ for the Yongji formation and dropping to $9 \mathrm{~m} / \mathrm{Ma}$ for the $\mathrm{Q}$ formation. The highest paleotemperature was reached during the Neocene $10 \mathrm{Ma}$ with a magnitude over $110^{\circ} \mathrm{C}$.

\section{Calibration}

The calibration of the basin geothermal models was done using the BHT temperature in order to determine the heat flow. The modeled maturity and temperature results have shown a good match with the measured properties (Figure 6), indicating the reliability of the modeled well to describe the thermal settings of the basin. Furthermore, the Tmax based Vitrinite reflectance has been plotted on the maturity charts, and a good tendency have been appreciated, certifying the capacity of this geothermal indicator to be used for calibration purposes.

\section{Source rock maturity}

A current heat flow of $64.1 \mathrm{~mW} / \mathrm{m}^{2}$ was calculated for the study area. The maturity and temperature chart suggest that two maturity stages have been reached; early and mid-mature. The maturation formation process described by the burial history established that the Shuangyang formation entered the oil threshold 0.5\%Ro during the Paleocene at $33 \mathrm{Ma}$. Afterwards, during the second uplift process $(30 \mathrm{Ma})$, the deepest sediments of the Sheling formation started the transition from immature to the early maturation stage reaching the oil generation phase (Figure 7). After the third uplift process, the deeper sediments of

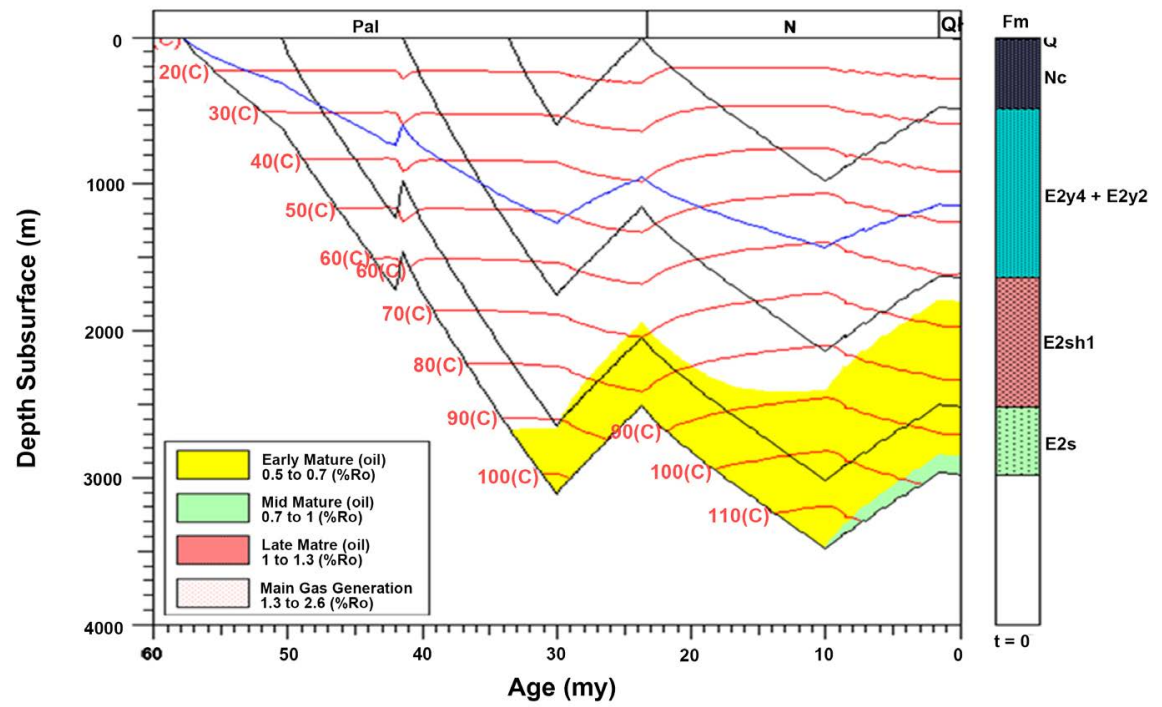

Figure 5. Burial history and maturity windows of the well Y8. 


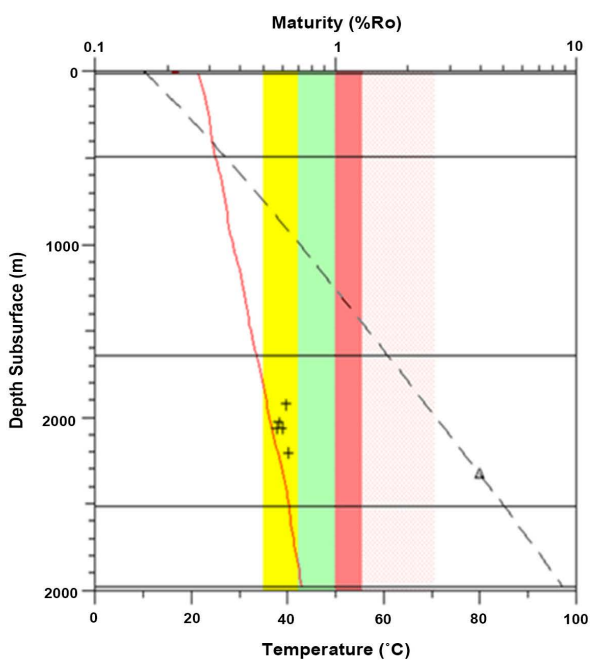

(a)
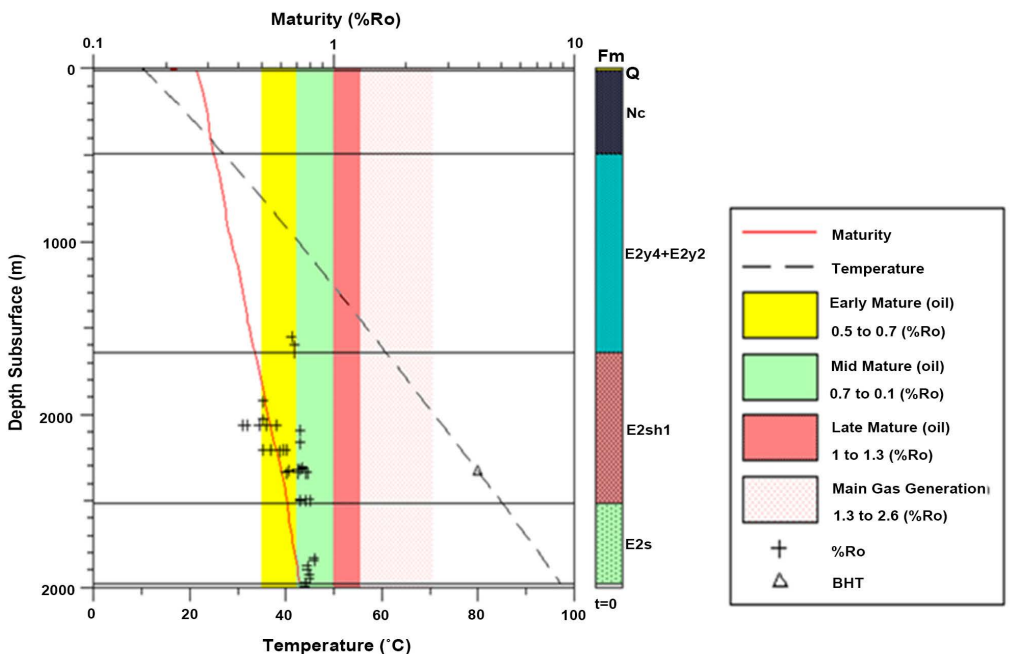

(b)

Figure 6. Maturity and temperature modeling of the well Y8 using two different maturity indicators. (a) Measured Vitrinite reflectance B. Tmax based Vitrinite reflectance.

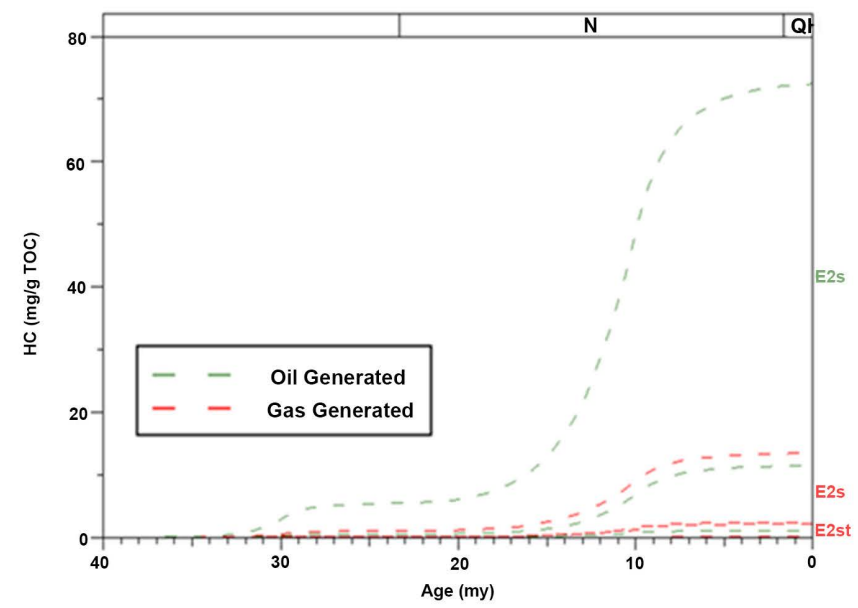

(a)

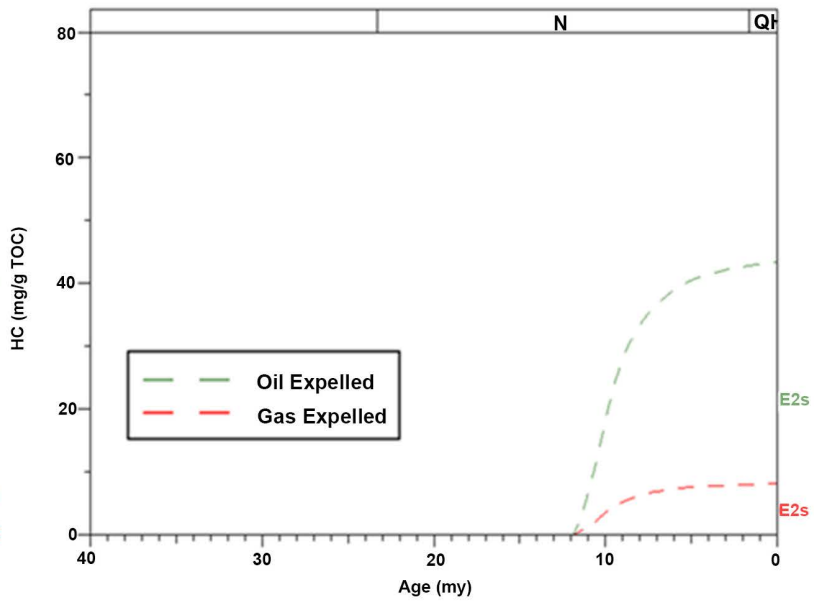

(b)

Figure 7. Hydrocarbon generation history of the well Y8's source rock.

the Shuangyang formation reached the mid maturity state. The Shuangyang and Sheling formations source rocks, yield oil and gas, being $34 \mathrm{Ma}$ the estimated generation time, however, only the Shuangyang formation expelled oil during the Neocene at $12 \mathrm{Ma} . \mathrm{Mg} / \mathrm{g}$ TOC.

The Shuangyang formation has been defined as the source rock with the highest hydrocarbon generation potential based on the oil and gas generated (Figure 7); generating $72 \mathrm{Mg} / \mathrm{g}$ TOC of oil and $13.42 \mathrm{Mg} / \mathrm{g}$ TOC of gas while the Sheling formation generated $11.24 \mathrm{Mg} / \mathrm{g}$ of oil and $2.12 \mathrm{Mg} / \mathrm{g}$ of gas. Concerning the oil and gas expulsion, the Shuangyang expelled up to the $60 \%$ of the oil generated ( $43 \mathrm{Mg} / \mathrm{g}$ TOC) and more than $68 \%$ of the gas ( $7.67 \mathrm{Mg} / \mathrm{g}$ TOC).

\section{Well Y34}


The well Y34 is located in the Ma'anshan fault step belt of the basin, between the wells $\mathrm{Y} 3$ and $\mathrm{Y} 38$.

\section{Erosion and sedimentation rate}

At this location, the three registered erosions had a magnitude of $200 \mathrm{~m}, 600$ $\mathrm{m}$ and $200 \mathrm{~m}$, showing a clear decrement tendency when compare with calculated missing thickness from wells Y8.

The burial history (Figure 8) shows a decreasing sedimentation rate tendency over the time, reaching it maximum rate during the formation of the Shuangyang formation $(150 \mathrm{~m} / \mathrm{Ma})$, and diminishing the amount of deposited sediments to $62 \mathrm{~m} / \mathrm{Ma}$ for the Sheling formation, followed by a slight increase to 65 for the Yongji and a finally declining for the $\mathrm{Nc}(51 \mathrm{~m} / \mathrm{Ma})$ and $\mathrm{Q}$ formation $(8.75 \mathrm{~m} / \mathrm{Ma})$. The highest paleotemperature was registered during the Neocene on the Shuangyang formation the over $120^{\circ} \mathrm{C}$.

\section{Calibration}

The model calibration performed by matching the BHT with the modeled temperature curved, generated a close acceptable match between the modeled maturity curved with the calculated Vitrinite reflectance, suggesting the reliability of the computer reconstructed well model (Figure 9).

\section{Source rock maturity}

The heat flow was estimated at $78.1 \mathrm{~mW} / \mathrm{m}^{2}$. The Shuangyang formation entered the principal stage of oil generation (0.5 - $1 \%$ Ro) during the Paleocene (37 $\mathrm{Ma})$, and currently all the formation reached the mature state having different levels of maturation (Figure 9): the maturity levels at the upper layer sediments is early mature, and at the lower formation layer is mid mature. The lower part of the Sheling formation achieved the oil generation stage during the Neocene (10 Ma) and is currently on early mature stage.

The Shuangyang formation generated oil and gas since the Paleocene at 43 $\mathrm{Ma}$, in two stages (Figure 10). The first stage took place from the $43 \mathrm{Ma}$ until the Neogene $20 \mathrm{Ma}$, generating hydrocarbon at constant rate over $20 \mathrm{Mg} / \mathrm{g}$ TOC.

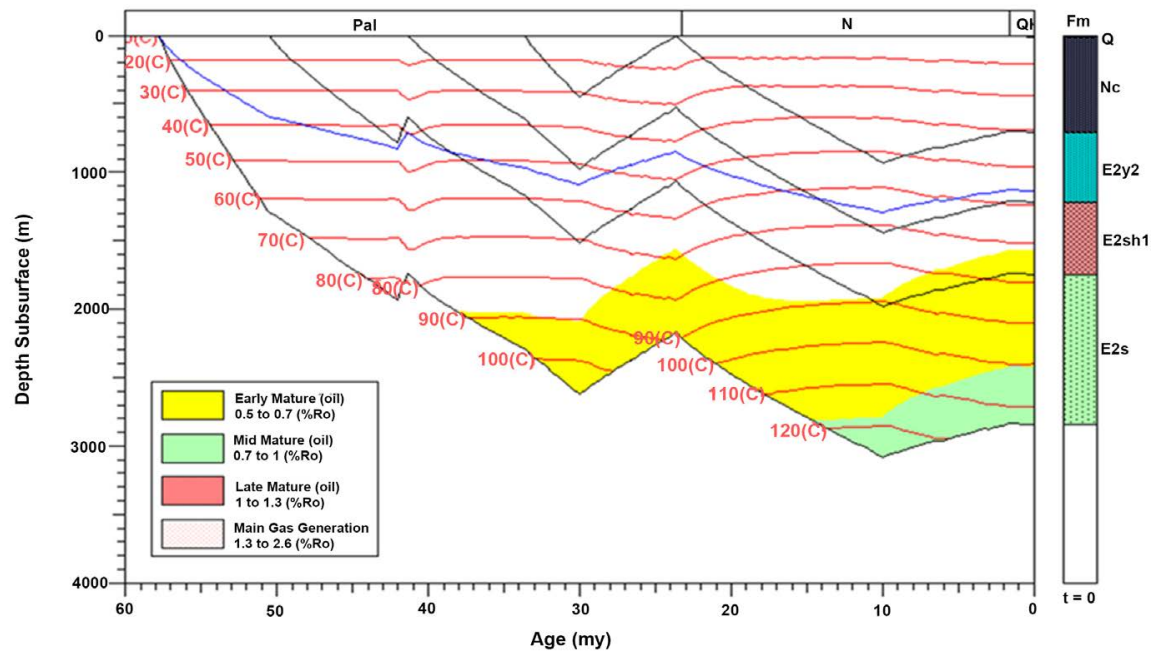

Figure 8. Burial history and maturity windows of the well Y34. 


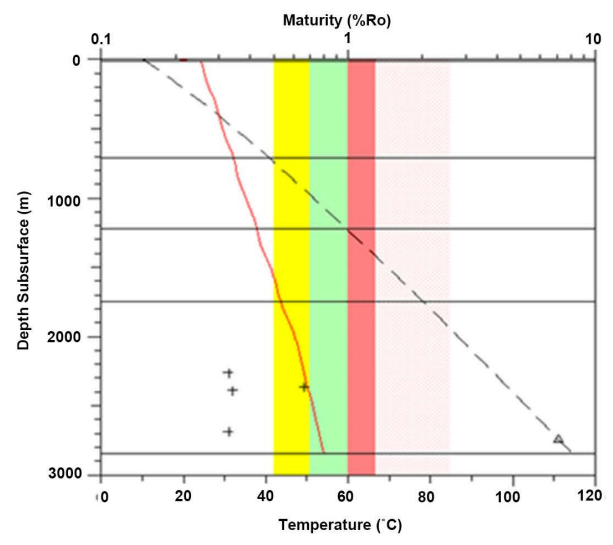

(a)

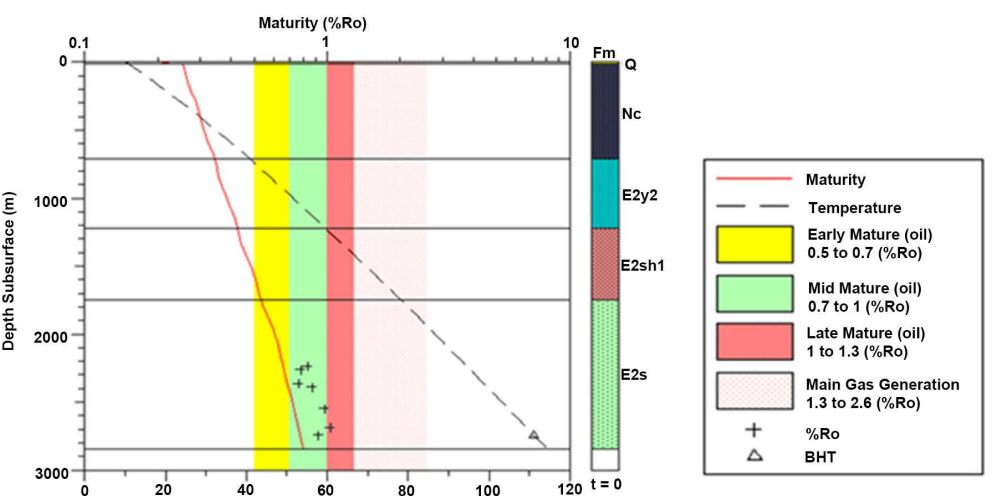

(b)

Figure 9. Maturity and temperature modeling of the well Y34 using two different maturity indicators: (a) Measured Vitrinite reflectance (b) Tmax based Vitrinite reflectance.

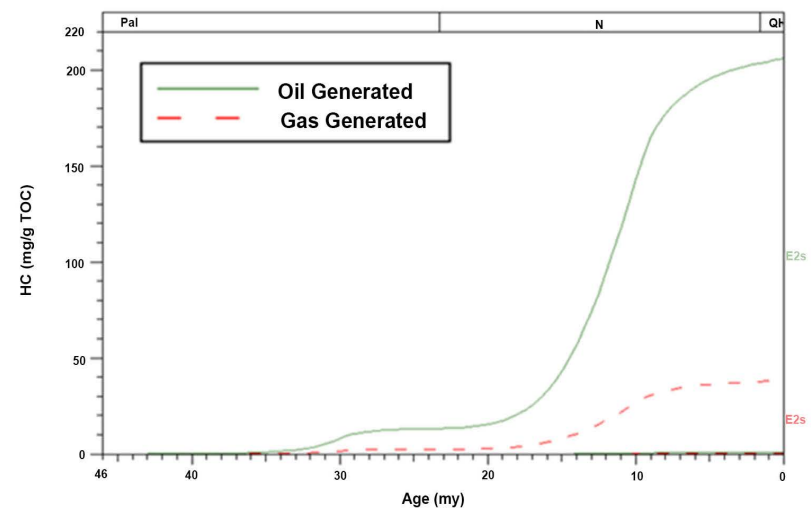

(a)

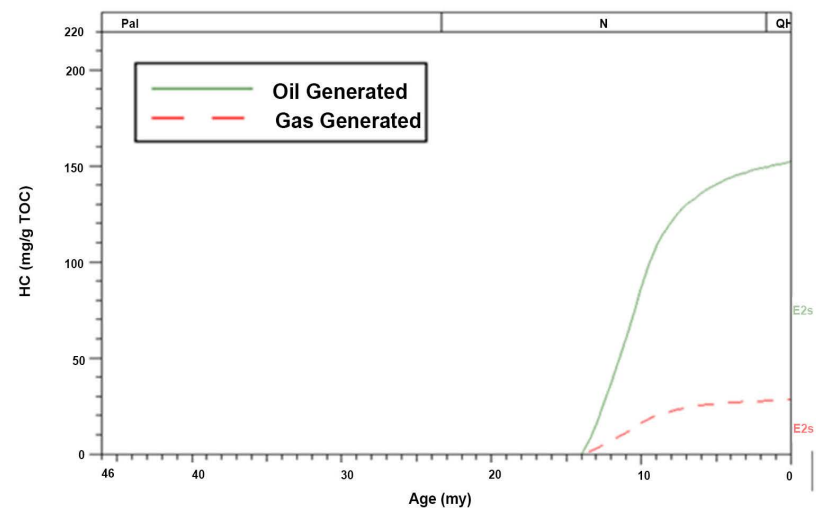

(b)

Figure 10. Hydrocarbon generation and expelling history of the well Y34's source rock.

After this point, the oil generation curved showed an exponential increase yielding up to $205.3 \mathrm{Mg} / \mathrm{g}$ TOC, and the gas generation was also incremented to $36 \mathrm{Mg} / \mathrm{g}$ TOC.

The hydrocarbon expulsion started during the Neocene $14 \mathrm{Ma}$, and reached $150 \mathrm{Mg} / \mathrm{g}$ TOC of oil and $27 \mathrm{Mg} / \mathrm{g}$ TOC of gas. The Sheling formation did not generate or expelled hydrocarbons.

\section{Well Y46}

The well Y46 is located at the southwest of the basin in the Jianshan uplift near the tectonic boundary.

\section{Erosion and sedimentation rate}

The sedimentation rate at the well's Y46 location shows the lowest level among the studied wells, reaching a peak of $98.75 \mathrm{~m} / \mathrm{Ma}$ during the Yongji source rock formation (Figure 11). As a consequence of the low sedimentation rate, the burial depth at this location was also the lowest among the studied basin wells, and lower paleotemperatures were generated. The maximum temperatures developed were experienced by the Shuangyang source rock, with values over $90^{\circ} \mathrm{C}$. 


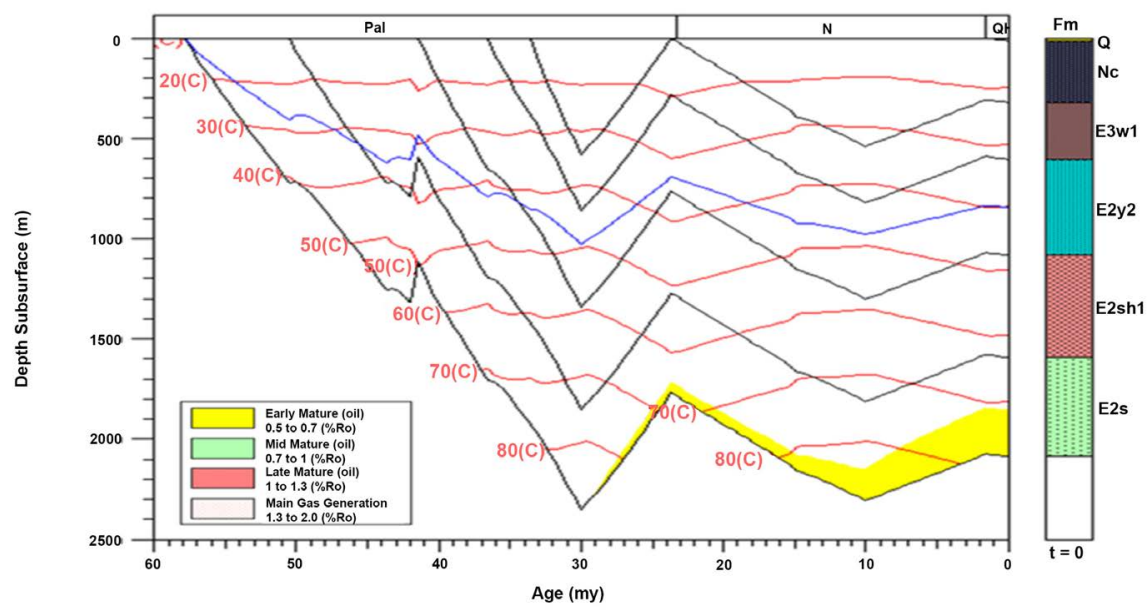

Figure 11. Burial history and maturity windows of the well Y46.

In addition to the low sedimentation rate, the erosions encountered by the formations are comparable in magnitude to the missing thickness calculated for the other wells. Consequently, the cooling effect produced by the rifting affected in a higher magnitude the geothermal settings at this location and the maturation of the source rocks.

\section{Calibration}

The simulated Temperature and the BHT data show a good match. Additionally, the maturity curved reaches the $0.5 \%$ Ro threshold at $2000 \mathrm{~m}$, as it was expected (Figure 12). These two elements suggest the reliability of the simulation.

\section{Source rock maturity}

The heat flow was estimated at $68.6 \mathrm{~mW} / \mathrm{m}^{2}$. As it was mention before, the low sedimentation rate and erosions experienced by the basin caused low paleotemperatures and low maturity in the basin. The Shuangyang formation was the only source rock that entered the oil generation stage during the Neogene (Figure 13); however, the generated oil and gas quantities are negligible: 1.25 $\mathrm{Mg} / \mathrm{g}$ TOC of oil and $0.22 \mathrm{Mg} / \mathrm{g}$ TOC of gas. This source rock did not expelled hydrocarbons.

\section{Summary}

The reconstruction of $1 \mathrm{D}$ thermal history modeling of the Moliqing basin was perform for 7 different locations that describe the different geological settings of the basin. The calculated basin heat flow magnitudes summarized in the Table 3 with values between 64 and $78.1 \mathrm{~mW} / \mathrm{m}^{2}$ suggest the Moliqing Basin is characterized with relative higher geothermal background. This geothermal characteristic of the Moliqing basin could favor the thermal maturation of kerogen, offering good conditions for hydrocarbon generation in the basin. The heat flow distribution of the wells Y38 and Y42 has a tendency to grow from the northwest to the southeast, and may attribute to the concentrating distribution of thicker mudstone or shale in northwest basin, which could block the deep geothermal transferring. 


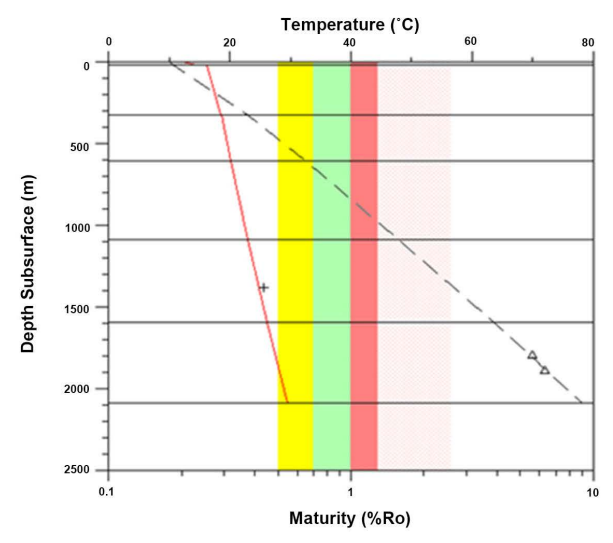

(a)
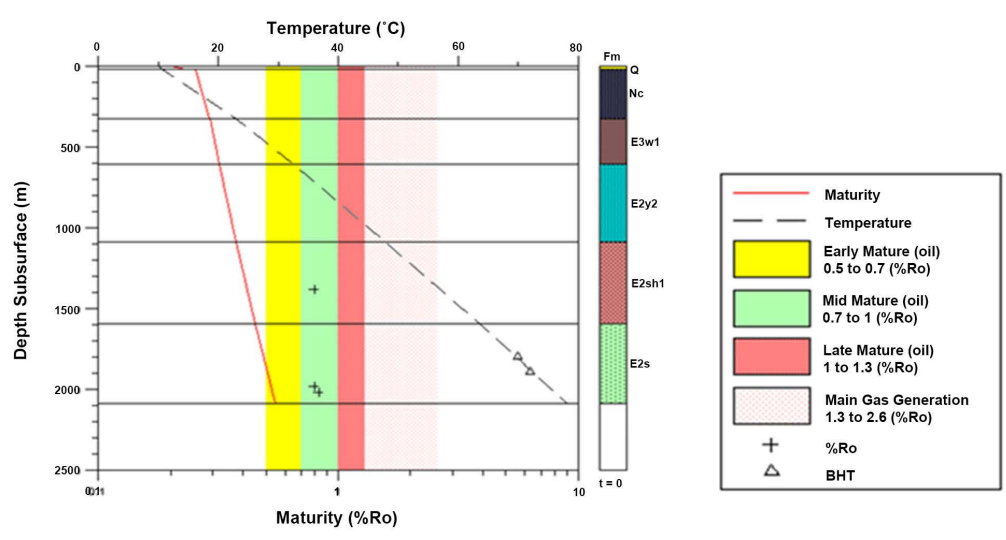

(b)

Figure 12. Maturity and temperature modeling of the well Y46 using two different maturity indicators: (a) Measured Vitrinite reflectance (b) Tmax based Vitrinite reflectance.

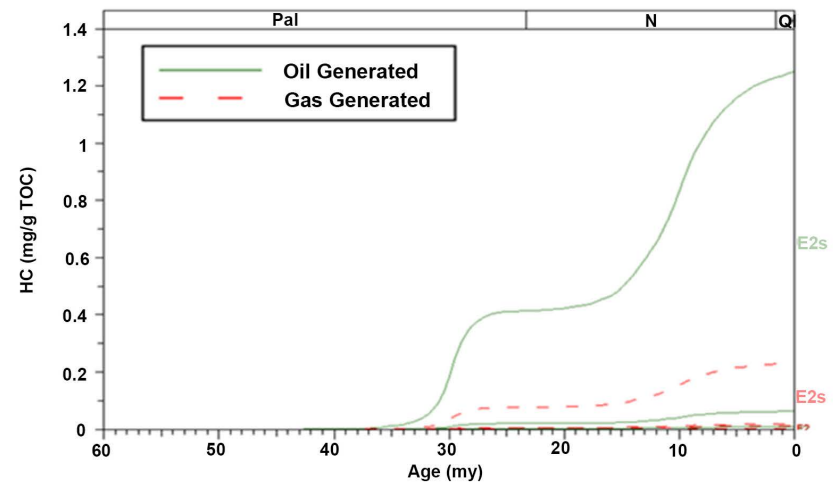

(a)

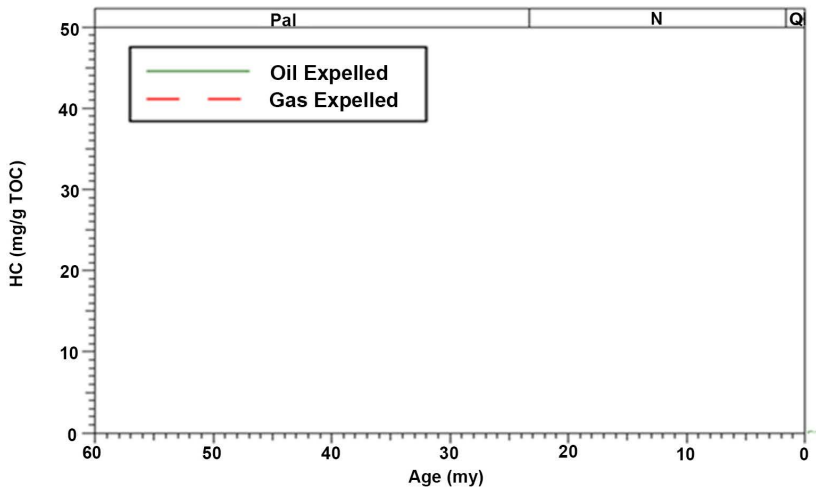

(b)

Figure 13. Hydrocarbon generation history of the well Y46's source rock.

Table 3. Summary of the $1 \mathrm{D}$ modeling heat flow and generation time calculations.

\begin{tabular}{|c|c|c|c|c|c|c|c|}
\hline \multirow[b]{2}{*}{ Well } & \multirow[b]{2}{*}{$\begin{array}{l}\text { Heat Flow } \\
{\left[\mathrm{mW} / \mathrm{m}^{2}\right]}\end{array}$} & \multirow[b]{2}{*}{$\begin{array}{l}\text { Generation } \\
\text { Time [Ma] }\end{array}$} & \multirow[b]{2}{*}{$\begin{array}{l}\text { Expulsion } \\
\text { Time [Ma] }\end{array}$} & \multicolumn{4}{|c|}{ Shuangyang Formation } \\
\hline & & & & $\begin{array}{c}\text { Oil } \\
\text { generation } \\
\mathrm{Mg} / \mathrm{g} \text { TOC }\end{array}$ & $\begin{array}{c}\text { Oil } \\
\text { expulsion } \\
\mathrm{Mg} / \mathrm{g} \text { TOC }\end{array}$ & $\begin{array}{c}\text { Gas } \\
\text { generation } \\
\mathrm{Mg} / \mathrm{g} \text { TOC }\end{array}$ & $\begin{array}{c}\text { Gas } \\
\text { expulsion } \\
\mathrm{Mg} / \mathrm{g} \text { TOC }\end{array}$ \\
\hline Y8 & 64.1 & 33 & 12 & 72 & 43 & 13.42 & 7.67 \\
\hline Y34 & 78.1 & 43 & 14 & 205 & 150 & 36 & 27 \\
\hline Y46 & 68.6 & 40 & - & 1.25 & - & 0.22 & - \\
\hline
\end{tabular}

The Shuangyang formation is the main source rock of the basin, having generated the majority of the oil and gas produced. The highest amount of generated and expelled oil was located at the location of the wells 34, where also the highest heat flow was estimated.

The Shuangyang and the Sheling formation reached the oil generation stage (0.5 - $1.3 \%$ Ro). Furthermore, the deepest sediments of the Moliqing Shuangyang formation reached mid maturity stage. 


\subsection{Two-Dimensional Thermal Modeling}

Thermal Maturity Results

Thermal Distribution and Maturity Effects

The geomorphology of the Moliqing basin, revealed by the use of the seismic cross sections, exposes an increase of the burial depth in two different directions. The first depth increment is presented along the basin main axis from the southwest to northeast. Additionally, a more dramatic increase is developed from the northwest towards the southeast boundary with differences up to 1800 m.

The modeled temperature profiles (Figure $14 \&$ Figure 15) indicate that the basin temperatures increase with the increment of the burial depth. Similarly, following the temperature tendency, the maturity levels of the source rocks also encounters a higher maturity level towards the deeper location. This is due to the impact that the temperature has on the maturity of the kerogen.

Regarding the BHT measurements, inaccuracies related to the recollection of the data could be responsible for the inconsistence. If the measuring time is shorter than standard, the gathered results would be below the real values. Nevertheless, the scale of the temperature differences suggests that this is not the case. The other cause could be related to the estimation of the thickness of the Shuangyang formation. During the drilling process, the Shuangyang formation was perforated, however, this stratum was never drilled completely, and its real thickness was never registered. The thickness of this formation was consequently calculated using the seismic spectrum in combination with the conversion equation $\mathrm{X}$, and, as it was described earlier the calculation is subjected to errors. If the calculated thickness was sub estimated, the reduction of the strata thickness would decrease the thermal gradient inside the basin, and higher temperatures will be reached. This scenario matched with what is presented in the seismic lines 2D models (Figure 14 \& Figure 15).

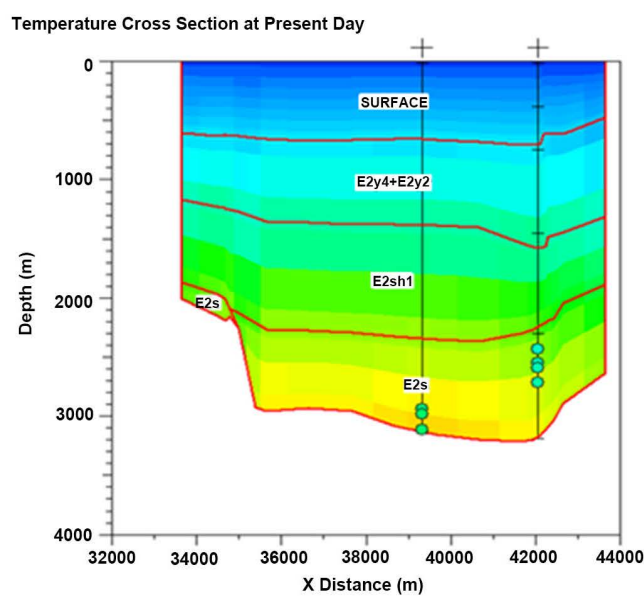

(a)

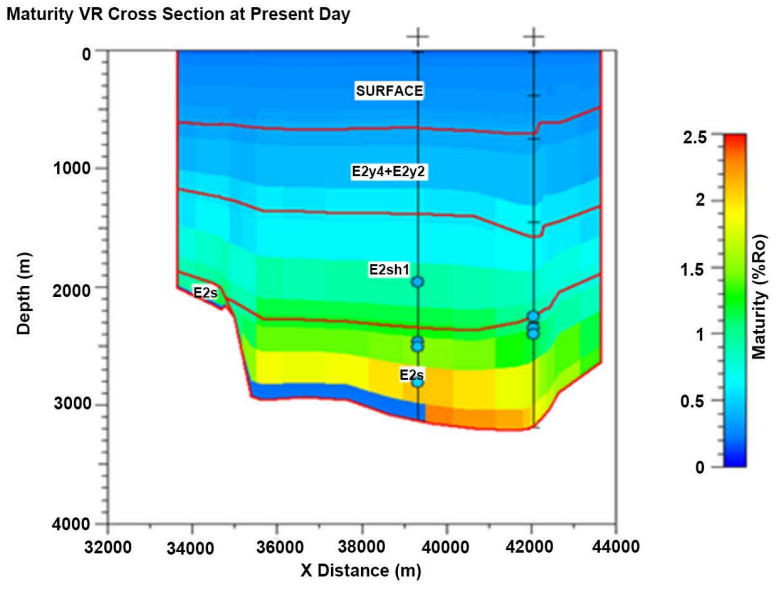

(b)

Figure 14. (a) Temperature cross section and (b) maturity cross section at present day for the Moliqing line 2 seismic line. 


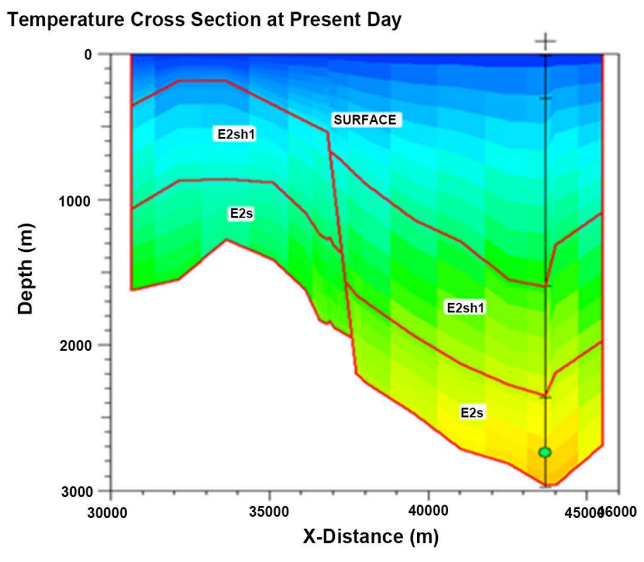

(a)

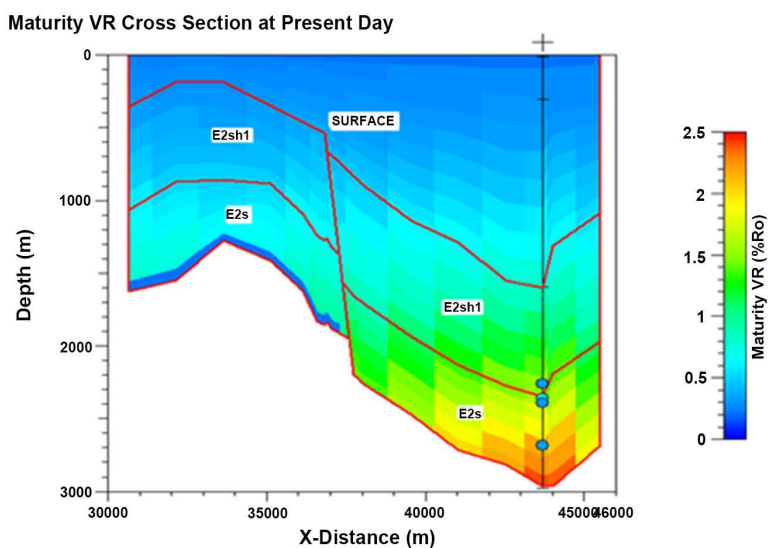

(b)

Figure 15. (a) Temperature cross section and (b) maturity cross section at present day for the Moliqing seismic line 5.

Due to the inconsistencies above explain, the assessment of a detailed maturity level distribution was not conclusive.

Nevertheless, from the modeled 2D seismic lines it is observable how the generative potential of the basin increases from the Yongji formation, to the Shuangyang.

The verification of the time-depth conversion equation is enhanced in order to increase the precision of the modeled geometry and faults distribution of the basin.

\section{Conclusions}

After a careful study of the Moliqing Basin in the Yitong Graben, The following conclusions are presented:

- The Tmax based calculated vitrinite reflectance provided acceptable results.

- The source rocks' TOC content varies accordingly to their relative basin location and to the depth. The source rock TOC rises from the northeast towards the southwest of the basin, and from the shallower strata to the deeper. Consequently, the Shuangyang formation is the source rock with the highest generative potential with level.

- The three source rocks present in the Moliqing basin, based on the evaluation using the Rock Eval Tmax, have been assessed as mature. These results agree with the results of previous scientific studies [3].

- The 2D modeling results were not conclusive due to the lack of reliable maturity indicators to constrain the model.

The main limitation of this study was related to the insufficient and unreliable data needed to characterize the source rock, and to reconstruct and constrain the basin models.

Further study is required to better understand the basin dynamics, especially the geological and geochemical. To achieve this, adequate and reliable data should be readily available. 


\section{Acknowledgements}

The authors are grateful to the Department of Oil and Gas exploration, Faculty of Earth Resources, China University of Geosciences (Wuhan) for their support in terms of data and finance.

\section{Conflicts of Interest}

The authors declare no conflicts of interest regarding the publication of this paper.

\section{References}

[1] Zhou, H.T., Huai, X.D., Li, P.Y., et al. (2006) Study of Eocene Lithologic Traps in Chaluhe Fault Depression of Yitong Basin. Global Geology, 25, 396-400.

[2] Sun, W.J., Bao, Z.L., Bao, Z.L., Ben, C.L., and Li, Z.S. (2004) Fault System and Tectonic Style of the Yitong Graben. Geoscience, 18, 505-601.

[3] Cao, Q. (2010) Dynamics of Hydrocarbon Accumulation.

[4] Tang, D., Chen, H., Sun, J., Zhang, H. and Chen, L. (2010) Cenozoic Tectonic Evolution of the Yitong Part of the Tan-Lu Fault Zone and Its Control on Yitong Basin. Geotectonica et Metallogenia, 34, 340-348.

[5] Cao, Q., Ye, J., Qing, H., Lu, J., Huang, S. and Tang, D. (2011) Pressure Evolution and Hydrocarbon Migration-Accumulation in the Moliqing Fault Depression, Yitong Basin, Northeast China. Journal of Earth Science, 22, 351-362. https://doi.org/10.1007/s12583-011-0187-4

[6] Deng, S.W., et al. (2007) Characteristic and Hydrocarbon Generation-Expulsion Histories of Source Rocks in Moliqing Rift of Yitong Basin. Geological Science and Technology Information, 26, 66-70.

[7] Xu, J. and Zhu, G. (1994) Tectonic Models of the Tan-Lu Fault Zone, Eastern China. International Geology Review, 36, 771. https://doi.org/10.1080/00206819409465487

[8] Wang, Y.C. (2001) The Petroleum System and Hydrocarbon Accumulation in the Yitong Graben. Petroleum Industry Press, 143-173.

[9] Perrier, R. and Quiblier, J. (1974) Thickness Changes in Sedimentary Layers during Compaction History; Methods for Quantitative Evaluations. Bulletin-AAPG, 58, 507-520. https://doi.org/10.1306/83D9142A-16C7-11D7-8645000102C1865D

[10] Haq, B.U. and Shutter, S.R. (2008) A Chronology of Paleozoic Sea-Level Changes. Science, 322, 64-68. https://doi.org/10.1126/science.1161648

[11] Harland, W.B., Armstrong, R.L., Cox, A.V., Craig, L.E., Smith, A.G. and Smith, D.G. (1990) A Geologic Time Scale 1989. Cambridge University Press, Cambridge.

[12] Steckler, M.S. and Watts, A.B. (1978) Subsidence of the Atlantic-Type Continental Margin off New York. Earth and Planetary Science Letters, 41, 1-13. https://doi.org/10.1016/0012-821X(78)90036-5

[13] Platte River Associates Inc. (2000) BasinMod 1D Basin Modelling System (Version 7.61).

[14] Sweeney, J.J. and Burnham, A.K. (1990) Evaluation of a Simple Model of Vitrinite Reflectance Based on Chemical Kinetics. American Association of Petroleum Geologists Bulletin, 74, 1559-1570. https://doi.org/10.1306/0C9B251F-1710-11D7-8645000102C1865D 
[15] Ungerer, P., Burrus, J., Doligez, B., Chenet, P.Y. and Bessls, F. (1990) Basin Evaluation by Integrated Two-Dimensional Modeling of Heat Transfer, Fluid Flow, Hydrocarbon Generation and Migration. American Association of Petroleum Geologists Bulletin, 74, 309-335.

https://doi.org/10.1306/0C9B22DB-1710-11D7-8645000102C1865D

[16] Pepper, A.S. and Corvi, P.J. (1995) Simple Kinetic Models of Petroleum Formation-Part I, Oil and Gas Generation from Kerogen. Marine and Petroleum Geology, 12, 291-319. https://doi.org/10.1016/0264-8172(95)98381-E 